\title{
Genetic factors as predictors of weight gain in young adult Dutch men and women
}

Citation for published version (APA):

van Rossum, C. T., Hoebee, B., Seidell, J. C., Bouchard, C., van Baak, M. A., de Groot, C. P., Chagnon, M., \& de Graaf, C. (2002). Genetic factors as predictors of weight gain in young adult Dutch men and women. International Journal of Obesity, 26(4), 517-528. https://doi.org/10.1038/sj.ijo.0801964

Document status and date:

Published: 01/01/2002

DOI:

10.1038/sj.ijo.0801964

Document Version:

Publisher's PDF, also known as Version of record

\section{Please check the document version of this publication:}

- A submitted manuscript is the version of the article upon submission and before peer-review. There can be important differences between the submitted version and the official published version of record.

People interested in the research are advised to contact the author for the final version of the publication, or visit the DOI to the publisher's website.

- The final author version and the galley proof are versions of the publication after peer review.

- The final published version features the final layout of the paper including the volume, issue and page numbers.

Link to publication

\footnotetext{
General rights rights.

- You may freely distribute the URL identifying the publication in the public portal. please follow below link for the End User Agreement:

www.umlib.nl/taverne-license

Take down policy

If you believe that this document breaches copyright please contact us at:

repository@maastrichtuniversity.nl

providing details and we will investigate your claim.
}

Copyright and moral rights for the publications made accessible in the public portal are retained by the authors and/or other copyright owners and it is a condition of accessing publications that users recognise and abide by the legal requirements associated with these

- Users may download and print one copy of any publication from the public portal for the purpose of private study or research.

- You may not further distribute the material or use it for any profit-making activity or commercial gain

If the publication is distributed under the terms of Article $25 \mathrm{fa}$ of the Dutch Copyright Act, indicated by the "Taverne" license above, 


\title{
Genetic factors as predictors of weight gain in young adult Dutch men and women
}

\author{
CTM van Rossum ${ }^{1 \star}$, B Hoebee $^{2}$, JC Seidell ${ }^{1}, C$ Bouchard $^{3}$, MA van Baak $^{4}$, CPGM de Groot $^{5}$, \\ $M$ Chagnon $^{3}, C$ de Graaf ${ }^{5}$ and WHM Saris ${ }^{4}$
}

${ }^{1}$ Department of Chronic Diseases Epidemiology, National Institute of Public Health and the Environment, Bilthoven, The Netherlands; ${ }^{2}$ Laboratory of Health Effects Research, National Institute of Public Health and the Environment, Bilthoven, The Netherlands; ${ }^{3}$ Pennington Biomedical Research Center, Louisiana State University, Baton Rouge, Louisiana, USA; ${ }^{4}$ Department of Human Biology, Maastricht University, Maastricht, The Netherlands; and ${ }^{5}$ Department of Human Nutrition and Epidemiology, Wageningen University, Wageningen, The Netherlands

OBJECTIVE: To investigate the association between DNA polymorphisms in several candidate genes for obesity and weight gain. Polymorphisms in these genes may contribute to weight gain through effects on energy intake, energy expenditure or adipogenesis.

DESIGN AND METHODS: From two large cohorts in the Netherlands (total 17500 adult men and women), we compared 286 subjects aged $20-40 y$ who gained an average of $12.8 \mathrm{~kg}$ (range $5.5-47 \mathrm{~kg}$ ) during a mean follow-up of $6.8 \mathrm{y}$ with 296 subjects who remained relatively constant over the same period with respect to occurrence of several polymorphisms in candidate genes of obesity and some lifestyle factors. Subjects who were dieting, were high alcohol consumers, were pregnant, changed their smoking status recently, or those who suffered from serious illnesses were excluded. Polymorphisms were determined in the LEPR-gene (LEPR Lys109Arg, LEPR Gln223Arg, LEPR Lys656Asn), in the UCP1 gene (A-G mutation at position-3826 5'region), in the UCP2 gene (Ala55Val, 45 bp Ins/Del), in the PPARG2 gene (Prol2Ala) and in the ADRB2 gene (Gly16Arg and Gln27Clu). RESULTS: With the exception of the Gly16Arg polymorphism in the ADRB2 gene in men $(P=0.04)$ and women $(P=0.05)$, and the Lys109Arg polymorphism in the LEPR gene in women, no statistically significant differences in the genotype and allele frequencies were observed between weight gainers and non-weight gainers. Weight gainers differed in some aspects of dietary habits and physical activity patterns: weight gainers consumed relatively more savory snacks and were less active during leisure time compared with non-weight gainers.

CONCLUSION: Only variations in the ADRB2 gene and LEPR gene, may contribute to susceptibility to weight gain. None of the other studied genetic markers were clearly associated with weight gain. Further research is necessary to establish the role of lifestyle factors, or interactions between genes or between genes and lifestyle factors on weight gain with age.

International Journal of Obesity (2002) 26, 517-528. DOl: 10.1038/5j/ijo/0801964

Keywords: weight gain; epidemiology; genetics; candidate genes; obesity; leptin receptor; adrenergic receptor; uncoupling protein; peroxisome proliferator-activated receptor

\section{Introduction}

Obesity is increasingly common especially but not exclusively in affluent societies and is a risk factor for a number of chronic diseases. ${ }^{1}$ Behavioral factors, such as physical activity level and dietary habits, are likely to be responsible for

\footnotetext{
*Correspondence: CTM van Rassum, Department of Chronic Diseases Epidemiology, National Institute of Public Health and the Environment, PO Box 1, 3720 BA Bilthoven, The Netherlands.

E-mail: caroline.van.rossum@rivm.n!
}

Received 5 November 2001; accepted 26 November 2001 this increase in prevalence. ${ }^{2,3}$ However, a large body of data suggests that genetic factors are also involved. These factors are thought to be associated with an increase in the predisposition to gain weight in the presence of adverse behavioral conditions. ${ }^{4-8}$

In recent years a large number of candiclate genes have been suggested to be involved in the development of human obesity. However, for none of these candidate genes is the association with obesity strong and consistent. ${ }^{8}$ This inconsistency might be explained by the different phenotypes used to assess obesity, eg body mass index (BMI), fat mass, or plasma leptin level. Another limitation of these candidate 
Genetic factors and weight gain CTM van Rossum et al

gene studies is that they have generally been based on small sample sizes or they were mostly performed in cross-sectional designs. Therefore, the genetic determinants for the development of obesity in the general population remain largely unidentified.

From a large general population, we have selected subjects whose weight remained relatively constant and subjects who gained weight over time. We described the characteristics and lifestyle factors of these two groups and we studied whether genetic variations are responsible for these differences in weight gain. We focused on nine common polymorphisms in five candidate genes which are potentially involved in the etiology of obesity: uncoupling protein genes (UCP1 and UCP2), which might play a role in energy expenditure and fat oxidation, ${ }^{9}$ the leptin receptor (LEPR) gene which might be involved in the regulation of food intake and energy balance; ${ }^{10,11}$ the peroxisome proliferatoractivated receptor- $\gamma 2$ (PPARG2) gene, which is thought to play a key role in adipogenesis, ${ }^{12}$ and the adrenergic- $\beta 2$ receptor (ADRB2) gene which is involved in the regulation of energy mobilization and utilization. ${ }^{13}$

\section{Methods}

\section{Study population}

Subjects were selected from participants in cardiovascular monitoring projects that have been carried out between
1987 and 1998 in two towns: Maastricht, a town in the south with about 100000 inhabitants; and Doetinchem, a small town with about 40000 inhabitants in the eastern part of The Netherlands. The initial aim of these projects was to monitor the major risk factors for cardiovascular disease. At baseline (in 1987-1991 and 1987-1997 for Doetinchem and Maastricht, respectively), men and women, aged 2059, had height and weight measurements at the Municipal Health Services. ${ }^{14}$ In Doetinchem, a second measurement occurred 6 years later in the period between 1993 and 1997, again at the Municipal Health Service. In Maastricht the follow-up weights were ascertained in 1998 by means of a self-administered questionnaire. Figures 1 and 2 show the time frame and the number of persons involved in the different projects in the two towns.

To exclude as much as possible the influence of potentially confounding factors for weight change, we excluded from these two cohorts all subjects at baseline and/or during the follow-up who reported to be on a diet, those consuming more than five glasses of alcoholic beverages per day, those with a history of chronic diseases, those who had recently changed their smoking habits (see Measurement section), those who were pregnant, and those with a follow-up of less than 4 years. Furthermore we excluded those of 40 years and above at baseline, because weight gain might be larger in the younger age groups. ${ }^{15}$ In addition, 102 persons out of 17743 were excluded for logistic reasons (eg no informed consent,

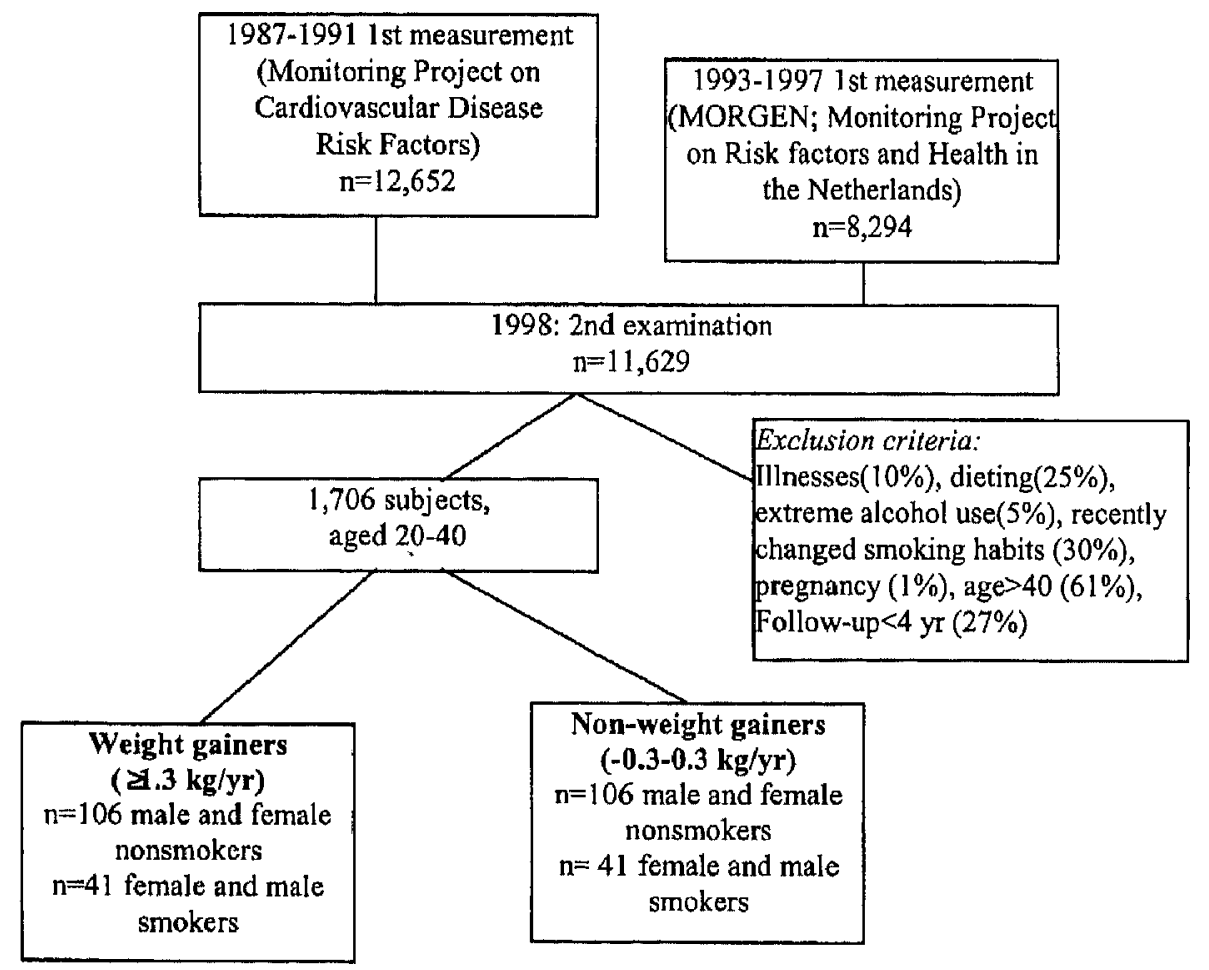

Figure 1 Selection of subjects from participants of cardiovascular monitoring projects in Maastricht. 


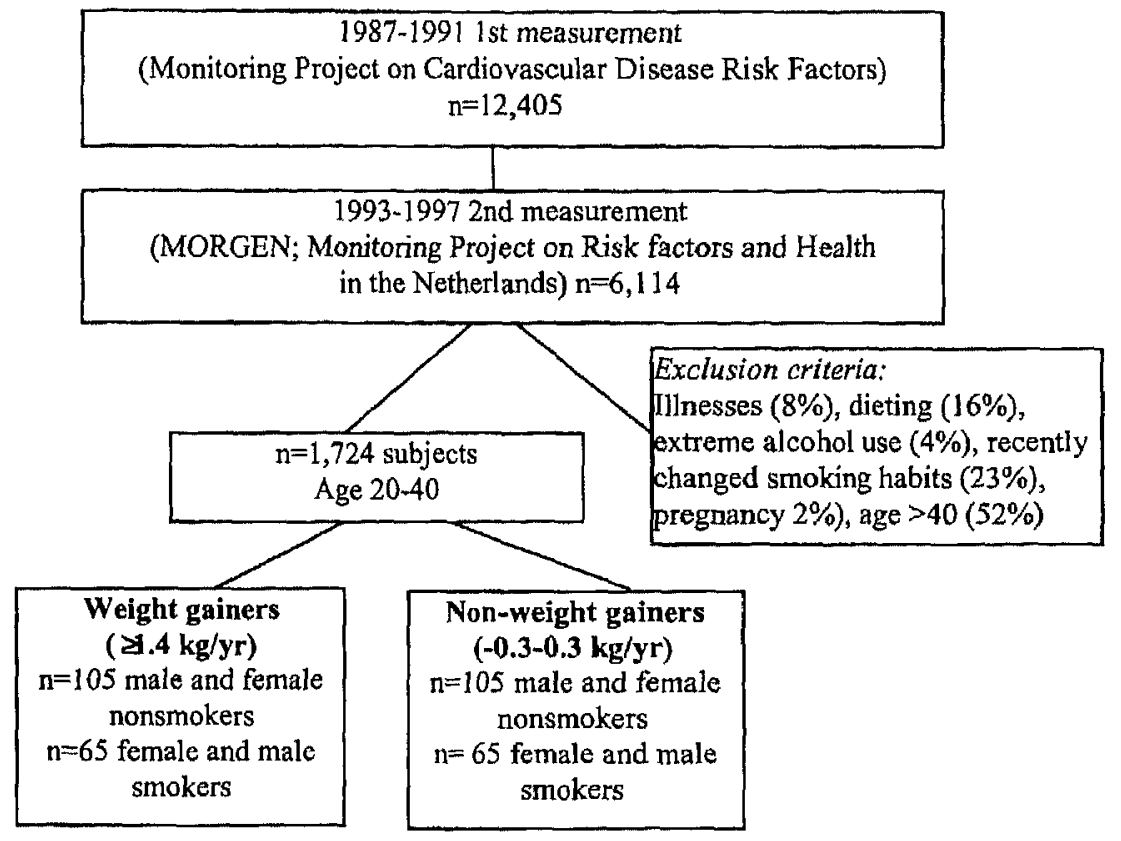

Figure 2 Selection of subjects from participants of cardiovascular monitoring projects in Doetinchem.

no blood sample, or no data on weight). From the remaining group ( $19 \%$ of the original sample), we selected the 'weight gainers' by taking the top decile of the distribution of average weight gain per year $(\geq 1.4$ and $\geq 1.3 \mathrm{~kg} / \mathrm{y}$ for the cohorts of Doetinchem and Maastricht, respectively). We randomly selected an equal sized group of subjects (='non-weight gainers') whose weight remained relatively constant (range: -0.3 to $+0.3 \mathrm{~kg} / \mathrm{y}$ ). The non-weight gainers were frequency matched for town, sex, age and smoking status with the weight gainers in a way that these two groups had not only the same marginal distributions but also the same joint distributions. All subjects had signed an informed consent to allow the use of stored blood samples for further scientific research. Finally, genomic DNA was successfully extracted from frozen blood samples for 296 weight gainers and 286 non-weight gainers.

\section{Measurements}

The examinations at baseline and the second measurement included physical examinations, eg anthropometric measurements, a self-administered questionnaire and blood sampling. However, for those in Maastricht, the second measurement included only a self-administered questionnaire.

Anthropometric measures. Weight at baseline was measured without shoes and wearing light indoor clothing. For all participants in Doetinchem weight was remeasured after 6 years in the same season as the initial measurement. For the participants from Maastricht, the second measurement was a self-reported weight. It is likely that subjects wore less clothing when measured at home compared with the measurement at the health center. To allow for the weight of clothing, we added $1.5 \mathrm{~kg}$ to the self-reported weight. This amount of $1.5 \mathrm{~kg}$ was based on some measurements performed by the investigators of the Municipal Health Center. BMI was calculated as weight divided by height squared. Weight gain was defined as the difference between the weight at baseline and the weight at the second examination. As the period of follow-up varied $(6 \mathrm{y}$ in Doetinchem and a range from $4.0 y$ to $11.3 \mathrm{y}$ in Maastricht), we calculated the average weight gain per year.

Characteristics of the study population. The questionnaires at baseline and/or follow-up provided information about history of chronic diseases, alcohol consumption, cigarette smoking, pregnancy, and educational level. Subjects were considered to have a history of chronic diseases when they had a self-reported history of myocardial infarction, coronary artery bypass operation or another heart operation, stroke, cancer or diabetes mellitus. Smoking history was categorized into 'non-smokers' (those who never smoked or stopped smoking more than $5 \mathrm{y}$ before the start of the study), 'smokers' (subjects who reported to be a current smoker at baseline as well as at the second measurement) and the remaining group (subjects who changed their smoking habits during the two measurements or stopped smoking less than 5 years before the start of the study). This last category was an exclusion category. The educational level, 
a measure for socioeconomic status, was classified into three categories: low (primary school, lower vocational/general education), medium (intermediate/higher general education, intermediate vocational education), and high (higher vocational education, university).

Lifestyle factors. At baseline, subjects were asked in the questionnaire about their physical activity level during work and leisure time. The answer categories for these questions varied from 'mainly sitting' to 'heavy physical activity' and from 'little exercise' to 'heavy exercise', respectively (see Table 2). For physical activity during leisure time, the first category was classified as 'inactive', the other three as 'active'. Information on food consumption was collected by means of a short semi-quantitative food-frequency questionnaire. This questionnaire included foods with a high contribution to the nutrients of interest in cardiovascular disease epidemiology, eg type of edible fat, milk products, and meat consumption. ${ }^{16}$ Information on physical activity and food consumption was available for 537 of the 582 subjects because these questions were only asked from 1987 to 1991.

Genotyping. Five candidate genes for energy intake, energy expenditure or adipogenesis which are of potential importance for weight gain, were selected. Genotyping was per- formed using PCR for UCP2 Ins/Del or PCR-restriction fragment length polymorphism (RFLP) analyses.

Two polymorphisms in the UCP2 gene were determined, a $\mathrm{C}$ to $\mathrm{T}$ nucleotide transition in exon 4 resulting in an Ala to Val substitution at codon $55^{17}$ and a 45 bp deletion/ insertion in the 3 -untranscribed region of exon $8 .{ }^{17}$ Furthermore we assayed an $A$ to $G$ transition at position-3826 5 'region in the UCP1 gene ${ }^{18}$ and a Prol2Ala missense mutation in the PPARG2 gene. ${ }^{19}$ In the LEPR gene, we determined three polymorphisms: a lysine to arginine substitution at codon 109 (Lys109Arg), a glutamine to arginine substitution at codon 223 (Glu223Arg) and a lysine to asparagine substitution at codon 656 (Lys656Asn). ${ }^{20}$ Finally, we investigated two polymorphisms in the ADRB2 gene, one at codon 16 substituting arginine for glycine (Gly16Arg) and one at codon 27 substituting glutamic acid for glutamine $(\mathrm{G} \ln 27 \mathrm{Glu}) .^{21}$ All genotyping methods are described in more detail elsewhere. ${ }^{17-22}$

\section{Data analyses}

Differences in characteristics, lifestyle factors, genotype and allele frequencies between weight gainers and non-weight gainers were analyzed with $t$-tests and chi-square tests. As weight at baseline was higher for the weight gainers compared to that of the non-weight gainers, we calculated weight-adjusted means and frequencies of the lifestyle and

Table 1 Characteristics of the study population (means (s.d.) or percentages)

\begin{tabular}{|c|c|c|c|c|c|c|}
\hline & \multicolumn{3}{|c|}{ Men } & \multicolumn{3}{|c|}{ Women } \\
\hline & $\begin{array}{l}\text { High weight gain } \\
\qquad(\mathrm{n}=134)\end{array}$ & $\begin{array}{l}\text { Stable weight } \\
\quad(n=138)\end{array}$ & P-value & $\begin{array}{l}\text { High weight gain } \\
\quad(\mathrm{n}=152)\end{array}$ & $\begin{array}{l}\text { Stable weight } \\
\qquad(n=158)\end{array}$ & P-value \\
\hline \multicolumn{7}{|l|}{ At baseline } \\
\hline Age $(y)$ & $28.1(5.9)$ & $28.9(5.6)$ & a & $29.9(6.0)$ & $29.9(5.9)$ & a \\
\hline \multicolumn{7}{|l|}{ Smoking status (\%) } \\
\hline Nonsmokers & 64.9 & 64.5 & $a$ & 67.1 & 67.1 & \\
\hline Smokers & 35.1 & 35.5 & & 32.9 & 32.9 & \\
\hline \multicolumn{7}{|l|}{ Town (\%) } \\
\hline Doetinchem & 53.7 & 49.3 & a & 63.2 & 59.5 & ${ }^{x}$ \\
\hline Maastricht & 46.3 & 50.7 & & 36.8 & 40.5 & \\
\hline Weight (kg) & $79.4(10.8)$ & $76.3(10.0)$ & 0.016 & $66.8(11.9)$ & $63.6(8.0)$ & 0.006 \\
\hline Height $(\mathrm{cm})$ & $1.82(0.07)$ & $1.80(0.07)$ & 0.020 & $1.68(0.07)$ & $1.67(0.06)$ & 0.27 \\
\hline \multicolumn{7}{|l|}{ BMI (\%) } \\
\hline$<18.5 \mathrm{~kg} / \mathrm{m}^{2}$ & 0.0 & 2.2 & & 3.3 & 3.2 & \\
\hline$\geq 18.5-<25.0 \mathrm{~kg} / \mathrm{m}^{2}$ & 68.7 & 65.2 & & 65.8 & 76.0 & \\
\hline$\geq 25.0-<30.0 \mathrm{~kg} / \mathrm{m}^{2}$ & 26.9 & 30.4 & & 23.9 & 19.0 & \\
\hline$\geq 30.0 \mathrm{~km} / \mathrm{m}^{2}$ & 4.5 & 2.2 & 0.13 & 7.3 & 1.9 & 0.068 \\
\hline BMI $\left(\mathrm{kg} / \mathrm{m}^{2}\right.$ & $24.1(3.0)$ & $23.7(2.8)$ & 0.45 & $23.8(3.9)$ & $22.9(2.8)$ & 0.02 \\
\hline \multicolumn{7}{|l|}{ Socioeconomic status (\%) } \\
\hline Low & 47.8 & 42.0 & & 57.2 & 48.1 & \\
\hline Medium & 41.0 & 37.7 & & 31.6 & 31.0 & \\
\hline High & 11.2 & 20.3 & 0.12 & 11.2 & 20.9 & 0.056 \\
\hline \multicolumn{7}{|l|}{ At end of follow-up } \\
\hline Follow-up time $(y)$ & $6.9(1.7)$ & $7.2(1.9)$ & 0.16 & $6.9(1.5)$ & $6.8(1.6)$ & 0.42 \\
\hline Weight (kg) & $92.0(11.5)$ & $76.8(10.0)$ & $\mathbf{b}$ & $79.7(13.3)$ & $64.2(8.0)$ & $b$ \\
\hline Weight gain $(\mathrm{kg} / \mathrm{y})$ & $1.86(0.53)$ & $0.06(0.17)$ & $b$ & $1.95(0.62)$ & $0.07(0.16)$ & $b$ \\
\hline $\mathrm{BMI}\left(\mathrm{kg} / \mathrm{m}^{2}\right)$ & $27.9(3.3)$ & $23.8(2.8)$ & b & $28.4(4.6)$ & $23.1(2.7)$ & b \\
\hline
\end{tabular}

a p-values not given, one of the matching variables.

b P-values not given, criteria for group selection. 
Table 2 Dietary habits and physical inactivity in weight gainers and those with stable weight, adjusted for baseline weight (means or percentages)

\begin{tabular}{|c|c|c|c|c|c|c|}
\hline \multirow[b]{2}{*}{ At baseline } & \multicolumn{3}{|c|}{ Men } & \multicolumn{3}{|c|}{ Women } \\
\hline & $\begin{array}{l}\text { High weight gain } \\
\qquad(n=123)\end{array}$ & $\begin{array}{l}\text { Stable weight } \\
\qquad(n=127)\end{array}$ & P-value & $\begin{array}{l}\text { High weight gain } \\
\qquad(n=142)\end{array}$ & $\begin{array}{l}\text { Stable weight } \\
\qquad(n=147)\end{array}$ & P-value \\
\hline Supplements (\% users) & 30.2 & 43.2 & 0.03 & 48.7 & 48.2 & 0.93 \\
\hline Sweeteners (\% users) & 7.1 & 1.0 & 0.02 & 14.3 & 11.5 & 0.48 \\
\hline \multicolumn{7}{|l|}{ Milk products (mean \% of total milk consumptions) } \\
\hline Skimmed milk (mean \%) & $25.5^{\mathrm{a}}$ & 27.2 & 0.63 & $40.7^{b}$ & 36.8 & 0.33 \\
\hline Semi-skimmed milk (mean \%) & 39.8 & 32.0 & 0.06 & $31.8^{\mathrm{b}}$ & 34.2 & 0.50 \\
\hline Full fat milk (mean \%) & $34.7^{\mathrm{a}}$ & 40.8 & 0.20 & $27.5^{b}$ & 28.9 & 0.73 \\
\hline \multicolumn{7}{|l|}{ Fruit $(\%)$} \\
\hline$<\frac{1}{2}$ times a day & 30.4 & 22.4 & & 22.9 & 17.5 & \\
\hline$\geq \frac{1}{2}$ times a week $-<1$ times a day & 23.1 & 25.7 & & 26.6 & 20.1 & \\
\hline$\geq 1$ times a day $-<2$ times a day & 38.6 & 43.7 & & 33.9 & 50.2 & \\
\hline$>2$ times a day & 7.8 & 8.2 & 0.55 & 16.5 & 12.1 & 0.05 \\
\hline \multicolumn{7}{|l|}{ Vegetables (\%) } \\
\hline$<\frac{1}{2}$ times a day & 12.7 & 16.1 & & 14.2 & 9.5 & \\
\hline$\geq \frac{1}{2}$ times a week $-<1$ times a day & 47.8 & 36.4 & & 34.2 & 38.2 & \\
\hline$\geq 1$ times a day $-<2$ times a day & 37.2 & 36.5 & & 44.9 & 45.0 & \\
\hline$>2$ times a day & 2.3 & 11.1 & 0.02 & 6.7 & 6.5 & 0.65 \\
\hline Sweet sandwich filling (mean \% of total number of fillings) & 23.8 & 22.3 & 0.59 & $24.6^{\mathrm{c}}$ & 29.6 & 0.05 \\
\hline \multicolumn{7}{|l|}{ Type of bread } \\
\hline White bread (\% consumers) & 27.9 & 20.3 & 0.17 & 16.5 & 13.5 & 0.46 \\
\hline Wheat bread ( $\%$ consumers) & 35.0 & 44.0 & 0.15 & 46.2 & 41.0 & 0.38 \\
\hline Wholemeal bread ( $\%$ consumers) & 41.7 & 43.0 & 0.84 & 42.5 & 50.8 & 0.16 \\
\hline \multicolumn{7}{|l|}{ Edible fats on bread d } \\
\hline Low-fat margarine (\% consumers) & 46.4 & 51.9 & 0.39 & $51.6^{\mathrm{e}}$ & 51.1 & 0.94 \\
\hline Margarine ( $\%$ consumers) & 44.0 & 36.9 & 0.26 & $30.5^{\mathrm{e}}$ & 31.5 & 0.86 \\
\hline Butter ( $\%$ consumers) & 13.9 & 18.8 & 0.30 & $14.8^{\mathrm{e}}$ & 17.5 & 0.54 \\
\hline No fat on bread (\% consumers) & 12.3 & 8.6 & 0.35 & $16.3^{e}$ & 16.8 & 0.90 \\
\hline \multicolumn{7}{|l|}{ Edible fats for dinner } \\
\hline Cooking fat or butter ( $\%$ consumers) & $30.2^{9}$ & 23.7 & 0.26 & $29.7^{\mathrm{h}}$ & 32.0 & 0.68 \\
\hline Margarine (\% consumers) & $64.4^{9}$ & 61.8 & 0.67 & $60.9^{h}$ & 61.9 & 0.87 \\
\hline Oil or linoleic acid-enriched margarine (\% consumers) & $34.8^{\mathrm{g}}$ & 43.8 & 0.15 & $36.9^{\mathrm{h}}$ & 38.9 & 0.74 \\
\hline \multicolumn{7}{|l|}{ Fish consumption (\%) } \\
\hline Never & 8.0 & 17.5 & & 13.1 & 13.4 & \\
\hline$<1$ times a month & 31.1 & 21.0 & & 29.0 & 24.7 & \\
\hline$\geq 1$ times a month $-<1$ times a week & 37.1 & 40.0 & & 28.4 & 30.9 & \\
\hline$\geq 1$ times a week & 23.8 & 21.9 & 0.07 & 29.5 & 31.1 & 0.87 \\
\hline \multicolumn{7}{|l|}{ Savory snacks (\%) } \\
\hline$<3.5$ times a week & 21.3 & 27.3 & & $20.9^{\mathrm{b}}$ & $32.3^{i}$ & \\
\hline$\geq 3.5$ times a week $-<1$ times a day & 37.0 & 48.4 & & $46.6^{\mathrm{b}}$ & $45.3^{1}$ & \\
\hline$\geq 1$ times a day & 41.6 & 24.2 & 0.01 & $32.5^{b}$ & $22.3^{\prime}$ & 0.04 \\
\hline \multicolumn{7}{|l|}{ Cookies or chocolate (\%) } \\
\hline$<3.5$ times a week & 53.0 & 52.6 & & 38.6 & 39.4 & \\
\hline$\geq 3.5$ times a week $-<1$ times a day & 24.0 & 29.5 & & 29.0 & 27.5 & \\
\hline$\geq 1$ times a day & 22.9 & 18.0 & 0.49 & 32.4 & 33.1 & 0.96 \\
\hline Alcohol consumption (\% abstainers) & 13.0 & 4.8 & 0.02 & 24.7 & 20.7 & 0.43 \\
\hline \multicolumn{7}{|l|}{ Physical activity during working time (\%) } \\
\hline Mainly sitting & 22.8 & 25.9 & & 12.4 & 16.9 & \\
\hline Sitting/standing and sometimes walking & 32.4 & 43.4 & & 34.0 & 32.3 & \\
\hline Walking & 32.9 & 19.3 & & 37.2 & 38.0 & \\
\hline Physically active & 6.1 & 4.3 & & 5.8 & 1.2 & \\
\hline Not applicable & 5.7 & 7.1 & 0.12 & 10.6 & 11.7 & 0.24 \\
\hline \multicolumn{7}{|l|}{ Physical activity during leisure time (\%) } \\
\hline Inactivel & 32.1 & 24.0 & & 44.3 & 31.8 & \\
\hline Active & 67.9 & 76.0 & 0.16 & 55.7 & 68.7 & 0.03 \\
\hline
\end{tabular}

${ }^{a} n=121$ because two persons are not consuming milk products.

$b_{n=141}$.

$c_{n=138}$.

dThese categories were not exclusive.

$e_{n=139}$

${ }^{\mathrm{t}}$ Contains $97 \%$ fat, suitable for frying and baking.

${ }^{9} n=122$.

$h_{n}=140$

$I^{\prime} n=144$.

I'nactive $=$ Little exercise.

${ }^{k}$ Active $=$ Exercise for at least 4 hours a week/Regular exercise/Regular strenuous exercise. 
Genetic factors and weight gain CTM van Rossum et al

522

genetic factors on the basis of analysis of covariance and logistic regression analyses. Subsequently, chi-square tests were done with the adjusted frequencies of the categorical variables.

Furthermore, we performed similar analyses in which the matching factors were also included in the model. To investigate the impact of more polymorphisms simultaneously on weight gain, we performed logistic regression analyses in which weight at baseline, two polymorphisms and its interaction term are included. To increase the power of these last analyses, the heterozygotes at each polymorphism were collapsed with the smallest group of homozygotes. For example, subjects with the Pro12/Ala12 and with the Ala12/Ala12 genotype in the PPARG gene were collapsed and compared with Pro12/Pro12. Genotype distributions of the non-weight gainers ${ }^{23}$ were tested for Hardy-Weinberg equilibrium by chi-square analyses. All analyses were performed separately in men and women using the statistical package SAS (version 6.11) and a P-value of 0.05 was considered as statistically significant.

\section{Results}

The characteristics of the study population are shown in Table 1. Subjects were on average 29.2 (s.d. \pm 5.9 ) y old and had a BMI at baseline of $23.6 \mathrm{~kg} / \mathrm{m}^{2}$ (s.d. \pm 3.2 ). Subjects with high weight gain increased on average $12.8 \mathrm{~kg}$ (range 5.5 $47 \mathrm{~kg}$ ) during a mean follow-up of $6.8 \mathrm{y}$, while the nonweight gainers gained on average $0.5 \mathrm{~kg}$ (range - 2.6$3.1 \mathrm{~kg}$ ). At baseline, male weight gainers did not differ in socioeconomic status, from the non-weight gainers. Male weight gainers already had a higher body weight at baseline compared with the non-weight gainers. However, they did not have a higher mean BMI, as they were also $2 \mathrm{~cm}$ taller compared with the non-weight gainers.

Among women, the socioeconomic status, based on the educational level, was slightly lower for the weight gainers compared with the weight keepers $(P=0.056)$. Furthermore, female weight gainers had a higher body weight, a similar height, and as a consequence a higher BMI at baseline compared with the female non-weight gainers. This difference in weight could not be explained by the differences in socioeconomic status (data not shown). The male and female weight gainers and non-weight gainers did not differ in mean blood pressure or mean plasma cholesterol concentration (data not shown).

As the unadjusted and the adjusted associations between weight gain and the lifestyle or genetic factors were mostly similar, only the weight-adjusted results are shown. Table 2 shows the weight-adjusted dietary factors and physical activity of the weight gainers and non-weight gainers. The male weight gainers used fewer vitamin and mineral supplements, but more sweeteners compared with the male non-weight gainers. Furthermore, the male weight gainers consumed slightly less full-fat milk products, but more semi-skimmed milk products compared with male non-weight gainers. No statistically significant differences were observed in fruit consumption, type of bread, sandwich filling, and type of edible fat used on bread or for dinner between these two groups. Compared to men with stable weight vegetables were less often consumed by male weight gainers. Male weight gainers tended to eat more frequently fish, beef or chicken (data not shown). Relatively more weight gainers were alcohol abstainers, while weight gainers consumed same type of alcoholic beverages (data not shown) compared to nonweight gainers. Finally, the male weight gainers consumed significantly more savory snacks compared with the nonweight gainers.

Among women, no statistically significant differences were observed in supplement use, in consumption of milk products, type of bread, type of edible fat, vegetables, meat (data not shown), or in alcohol consumption between the weight gainers and weight keepers. Fruit was less often consumed by the female weight gainers and their sandwiches were less often filled with sweet products compared with those of female non-weight gainers. Finally, also among women an association was observed between frequent use of savory snacks and weight gain. There were no statistically significant differences in physical activity during working time or during leisure time between the two male groups ( $P=0.12$ and $P=0.16$, respectively). Among women, no significant differences were found in physical activity level during working time. However, during leisure time, nonweight gainers exercised more often compared with those who gained most in weight $(P=0.03)$.

Table 3 shows the weight-adjusted genotype frequencies for all studied DNA-polymorphisms of the weight gainers and the non-weight gainers. No consistent associations were observed. The only statistically significant association with weight gain was found among men with the Gly16Arg polymorphism in the ADRB2-gene: weight gainers were more often homozygous, either Gly/Gly or Arg/Arg, and less often heterozygous for this polymorphism $(P=0.04)$. This association was not observed among women, in fact the percentage of homozygotes for Gly/Gly was higher in the group of weight gainers compared with the non-weight gainers (not shown in table; $P=0.05$ ). Furthermore some (non-significant) trends were found among women between polymorphisms of the LEPR-gene and weight gain; weight gainers tended more often to be carriers of the Lys allele at codon 109 (allele frequencies Lys109 74\% vs 68\%; $P=0.09$ ); and the Arg/Arg genotype at codon 223 was slightly underrepresented in weight gainers ( $16 \%$ vs $25 \% ; P=0.07)$. AlI genotype distributions were found to be in Hardy - Weinberg equilibrium with the exception of the distribution of ADRB2Gly16Arg in the male non-weight gainers ( $P=0.03$ ).

We also investigated the combined effect of two polymorphisms on weight gain. From all combinations, only a few (see Table 4) showed a statistically significant interaction term. For men, a significant interaction term was observed between the $A(-3826) \mathrm{G}$ polymorphism in the UCP-1 gene and the Lys656Asn polymorphism in the LEPR gene, as well 
Table 3a Genotype frequencies for male weight gainers and those with stable weight, adjusted for weight at baseline (percentages)

\begin{tabular}{|c|c|c|c|c|}
\hline & \multicolumn{4}{|c|}{ Men } \\
\hline & High weight gain $(n=134)$ & Stable weight $(n=138)$ & P-value & $O \mathrm{R}^{\mathrm{a}}\left(95 \% \mathrm{Cl}^{\mathrm{b}}\right)$ \\
\hline \multicolumn{5}{|c|}{ UCP1 A $(-3826) G(\%)$} \\
\hline $\mathrm{A} / \mathrm{A}$ & 55.3 & 52.1 & & 1 (ref) \\
\hline$A / G$ & 38.1 & 38.4 & & $0.93(0.61-1.4)$ \\
\hline $\mathrm{G} / \mathrm{G}$ & 6.6 & 9.5 & 0.66 & $0.65(0.30-1.4)$ \\
\hline \multicolumn{5}{|c|}{ UCP2 Ins/Del (\%) } \\
\hline Del/Dei & 55.3 & 52.1 & & $1(\mathrm{ref})$ \\
\hline Ins/Del & 38.1 & 38.4 & & $1.14(0.74-1.7)$ \\
\hline Ins/Ins & 6.6 & 9.5 & 0.66 & $0.94(0.42-2.1)$ \\
\hline \multicolumn{5}{|c|}{ UCP2 Ala55Val (\%) } \\
\hline Ala/Ala & 45.5 & 48.5 & & 1 (ref) \\
\hline Ala/Val & 39.2 & 38.1 & & $1.10(0.71-1.7)$ \\
\hline Val/Val & 15.3 & 13.4 & 0.85 & $1.22(0.66-2.3)$ \\
\hline \multicolumn{5}{|c|}{ LEPR Lys109Arg (\%) } \\
\hline Lys/Lys & 56.4 & 53.9 & & 1 (ref) \\
\hline Lys/Arg & 37.6 & 37.4 & & $0.96(0.63-1.5)$ \\
\hline $\mathrm{Arg} / \mathrm{Arg}$ & 6.0 & 8.7 & 0.69 & $0.66(0.29-1.5)$ \\
\hline \multicolumn{5}{|c|}{ LEPR Gln223Arg (\%) } \\
\hline $\mathrm{Gln} / \mathrm{Gln}$ & 33.9 & 32.3 & & 1 (ref) \\
\hline Gln/Arg & 46.4 & 48.5 & & $0.91(0.58-1.4)$ \\
\hline $\mathrm{Arg} / \mathrm{Arg}$ & 19.7 & 19.2 & 0.94 & $0.98(0.55-1.5)$ \\
\hline \multicolumn{5}{|c|}{ LEPR Lys656Asn (\%) } \\
\hline Lys/Lys & 60.3 & 66.9 & & 1 (ref) \\
\hline Lys/Asn & 37.4 & 27.5 & & $1.50(0.97-2.3)$ \\
\hline Asn/Asn & 2.4 & 5.7 & 0.11 & $0.47(0.15-1.5)$ \\
\hline \multicolumn{5}{|c|}{ PPARG2 Pro12Ala (\%) } \\
\hline Pro/Pro & 75.4 & 79.7 & & 1 (ref) \\
\hline Pro/Ala & 23.1 & 20.3 & & $0.85(0.54-1.3)$ \\
\hline Ala/Ala & 1.5 & 0 & 0.29 & $1.05(0.10-10.9)$ \\
\hline \multicolumn{5}{|c|}{ A.DRB2 Gly16Arg (\%) } \\
\hline Cly/Gly & 43.9 & 35.6 & & 1 (ref) \\
\hline Gly/Arg & 39.9 & 54.7 & & $0.59(0.38-0.92)$ \\
\hline Arg/Arg & 16.1 & 9.7 & 0.04 & $1.36(0.70-2.6)$ \\
\hline \multicolumn{5}{|c|}{ ADRB2 Gln27Clu (\%) } \\
\hline $\mathrm{G} \ln / \mathrm{G} \ln$ & 30.7 & 26.7 & & 1 (геf) \\
\hline Cln/Glu & 53.0 & 55.8 & & $0.83(0.52-1.3)$ \\
\hline Glu/Glu & 16.3 & 17.5 & 0.77 & $0.81(0.44-1.5)$ \\
\hline
\end{tabular}

${ }^{a}$ Odds rations. ${ }^{b}$ Confidence interval.

as between the Lys 109Arg polymophism in the LEPR gene and the UCP2 Ins/Del polymorphism. The risk of high weight gain was the highest for men with the A/A genotype and one or two Asn 656 alleles (OR 2.4, 95\% Cl 1.1-4.9), and for men with one or two Ins alleles and also one or two Arg109 alleles (OR 1.14, 0.54-2.4) Furthermore, significant effects were observed among women for the combination of Gly16Arg polymorphism in the ADRB2 gene and the UCP2 Ins/Del polymorphism, and for the combination of the same polymorphism in the ADRB2 gene and the PPARG2 Pro12Ala polymorphism: the risk on high weight gain was the largest for women with the Del/Del and Arg16/+ genotypes (OR $2.7,1.3-5.4$ ), and for the female carriers of the Ala 12 and also the Arg 16 alleles (OR 1.6, 0.8-3.4).

\section{Discussion}

We observed that one polymorphism in the ADRB2 gene and one in the LEPR gene, but none in the other candidate genes was significantly associated with weight gain. In addition, some aspects of dietary habits and physical activity patterns were associated with weight gain.

A number of issues need to be addressed before the results can be interpreted. First, the issue of potential selection bias. The participation rate in the original cohort was about $50 \% .{ }^{14}$ It is unlikely, however, that among the weight gainers and those who kept stable weight there was selective participation by genotype. Furthermore, we excluded subjects on the basis of some baseline measurements and measurements at the end of the follow-up. However, as not all measurements were for $100 \%$ representative of the situation during the follow-up, it is still possible that some of the differences between the weight gainers and weight stable group can be attributed by differences in the selection criteria.

Among the male non-weight gainers we observed a slight departure from a Hardy-Weinberg Equilibrium (HWE) for the Gly16Arg polymorphism in the ADRB2 gene. Prudence is called for drawing conclusions from this, since it is still possible that the general population is in HWE; Schaid et al mentioned that, when a true association exists, the expected 
Table 3b Genotype frequencies for female weight gainers and those with stable weight, adjusted for weight at baseline (percentages)

\begin{tabular}{|c|c|c|c|c|}
\hline & \multicolumn{4}{|c|}{ Women } \\
\hline & High weight gain $(n=152)$ & Stable weight $(n=158)$ & P-value & $\mathrm{OR}^{\mathrm{a}}\left(95 \% \mathrm{Cl}^{\mathrm{b}}\right)$ \\
\hline \multicolumn{5}{|c|}{ UCPl A $(-3826)$ C (\%) } \\
\hline$A / A$ & 62.3 & 58.4 & & 1 (ref) \\
\hline $\mathrm{A} / \mathrm{G}$ & 30.3 & 35.4 & & $0.80(0.53-1.2)$ \\
\hline$G / G$ & 7.4 & 6.1 & 0.61 & $1.13(0.53-2.4)$ \\
\hline \multicolumn{5}{|c|}{ UCP2 Ins/Del (\%) } \\
\hline Del/Det & 62.3 & 58.4 & & 1 (ref) \\
\hline Ins/Del & 30.3 & 35.4 & & $0.99(0.67-1.5)$ \\
\hline Ins/Ins & 7.4 & 6.1 & 0.61 & $1.00(0.48-2.1)$ \\
\hline \multicolumn{5}{|c|}{ UCP2 Ala55Val (\%) } \\
\hline Ala/Ala & 37.7 & 37.2 & & 1 (ref) \\
\hline Ala/Val & 43.6 & 42.3 & & $1.02(0.67-1.6)$ \\
\hline Val/Nal & 18.8 & 20.6 & 0.92 & $0.90(0.53-1.5)$ \\
\hline \multicolumn{5}{|c|}{ LEPR Lys109Arg (\%) } \\
\hline Lys/Lys & 56.0 & 48.6 & & 1 (ref) \\
\hline Lys/Arg & 36.5 & 38.9 & & $0.82(0.54-1.2)$ \\
\hline Arg/Arg & 7.4 & 12.5 & 0.23 & $0.52(0.26-1.0)$ \\
\hline \multicolumn{5}{|c|}{ LEPR GIn223Arg (\%) } \\
\hline$G \ln / G \ln$ & 31.4 & 29.2 & & 1 (ref) \\
\hline Gln/Arg & 52.3 & 45.9 & & $1.06(0.68-1.6)$ \\
\hline $\mathrm{Arg} / \mathrm{Arg}$ & 16.3 & 24.9 & 0.17 & $0.61(0.35-1.1)$ \\
\hline \multicolumn{5}{|c|}{ LEPR Lys656Asn (\%) } \\
\hline Lys/Lys & 69.1 & 65.1 & & 1 (ref) \\
\hline Lys/Asn & 27.4 & 31.9 & & $0.81(0.53-1.2)$ \\
\hline Asn/Asn & 3.5 & 3.0 & 0.68 & $1.17(0.38-3.3)$ \\
\hline \multicolumn{5}{|c|}{ PPARG2 Pro12Ala (\%) } \\
\hline Pro/Pro & 76.7 & 73.7 & & 1 (ref) \\
\hline Pro/Ala & 22.6 & 25.7 & & $1.20(0.73-2.0)$ \\
\hline Ala/Ala & 0.7 & 0.6 & 0.81 & - \\
\hline \multicolumn{5}{|c|}{ ADRB2 Gly16Arg (\%) } \\
\hline Gly/Gly & 34.7 & 45.7 & & 1 (ref) \\
\hline Gly/Arg & 53.3 & 44.5 & & $1.58(1.1-2.4)$ \\
\hline $\mathrm{Arg} / \mathrm{Arg}$ & 12.2 & 9.8 & 0.14 & $1.63(0.85-3.1)$ \\
\hline \multicolumn{5}{|c|}{ ADRB2 Gln27Glu (\%) } \\
\hline $\mathrm{Gln} / \mathrm{Cln}$ & 34.4 & 31.5 & & $1(\mathrm{ref})$ \\
\hline Gln/Glu & 45.7 & 49.1 & & $0.86(0.56-1.3)$ \\
\hline Glu/Glu & 19.9 & 19.4 & 0.82 & $0.94(0.55-1.6)$ \\
\hline
\end{tabular}

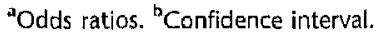

genotype proportions among the diseased can deviate from HWE even if the general population is in HWE. ${ }^{23}$ In our study this can be argued for the weight gainers as well as the non-weight gainers. Therefore, we do not assume that the departure accounts for the association found between the polymorphism in the ADRB2 gene and weight gain.

An advantage of our study was our prospective design to study simultaneous the association between lifestyle factors or genetic variation and weight. As lifestyle factors might affect weight gain, and a higher weight could in turn influence someone's lifestyle, cross-sectional and longitudinal studies on the etiology of obesity can generate completely opposite conclusions. ${ }^{24}$ Our findings could still be affected by misclassification problems. For the subjects from Maastricht, the weights at the end of the follow-up were selfreported. As errors in self-reported weight increase with the magnitude of overweight, this misclassification is probably not randomly distributed. ${ }^{25}$ However, we assumed that the ranking among weight gainers and those who remained weight stable was not affected by self-report. Admittedly, information on dietary food frequency and physical activity was relatively crude and does not allow careful evaluation of their role as predictor of weight gain. Instead, this information should be interpreted for the purpose of description rather than hypothesis testing. One advantage compared to cross-sectional studies on obesity and lifestyle factors is that we collected information on these variables when the subjects were still lean and the bids of misreporting may have been excluded.

Finally, some factors, such as weight at baseline or the matching factors could have confounded our results. Fortunately, these biases were of minor importance, as similar results were found with and without adjustment for baseline weight or the matching factors (data not shown).

The published evidence for associations between candidate genes and obesity-related phenotypes is conflicting. For instance, associations were found between the Arg16 variant of the ADRB2 gene with BMI, waist and hip circumferences among French men, ${ }^{26}$ and with BMI among Japanese women, ${ }^{27}$ but not among French women and Japanese 
Genetic factors and weight gain

CTM van Rossum et al

Table 4 The significant combinations of two polymorphisms on the risk of weight gain (odds ratios)

\begin{tabular}{|c|c|c|c|c|c|}
\hline \multirow[b]{2}{*}{ Polymorphism 1} & \multicolumn{4}{|c|}{ Polymorphism 2} & \multirow[b]{2}{*}{ P-Interaction } \\
\hline & $\mathrm{n} / \mathrm{n}^{\mathrm{a}}$ & $O R^{\mathrm{b}}(95 \% C I)$ & $n / n$ & OR $(95 \% \mathrm{Cl})$ & \\
\hline Men & \multicolumn{4}{|c|}{ LEPR Lys656Asn } & \\
\hline UCP1 $A(-3826) G$ & \multicolumn{2}{|c|}{ Lys/Lys } & \multicolumn{2}{|c|}{ Lys/Asn or Asn/Asn } & \\
\hline $\mathrm{A} / \mathrm{A}$ & $44 / 54$ & 1 (ref.) & $31 / 17$ & $2.37(1.1-4.9)$ & \\
\hline$A / G$ or $G / G$ & $37 / 38$ & $1.30(0.70-2.4)$ & $22 / 29$ & $0.98(0.49-2.0)$ & 0.030 \\
\hline Men & \multicolumn{4}{|c|}{ LEPR Lys109Arg } & \\
\hline UCP2 Ins/Del & \multicolumn{2}{|c|}{ Lys/Lys } & \multicolumn{2}{|c|}{ Lys/Arg or Arg/Arg } & \\
\hline Del/Del & $43 / 32$ & 1 (ref.) & $29 / 44$ & $0.53(0.27-1.0)$ & \\
\hline Ins/Del or Ins/Ins & $33 / 42$ & $0.64(0.33-1.2)$ & $29 / 20$ & $1.14(0.55-2.4)$ & 0.016 \\
\hline Women & \multicolumn{4}{|c|}{ ADRB2 Gly16Arg } & \\
\hline UCP2 Ins/Del ' & \multicolumn{2}{|c|}{ Gly/Gly } & \multicolumn{2}{|c|}{ Gly/Arg or Arg/Arg } & \\
\hline Del/Del & $21 / 39$ & 1 (ref.) & $50 / 35$ & $2.69(1.3-5.4)$ & \\
\hline Ins/Del or Ins/Ins & $32 / 33$ & $1.77(0.85-3.7)$ & $49 / 51$ & $1.78(0.91-3.5)$ & 0.040 \\
\hline Women & \multicolumn{4}{|c|}{ ADRB2 Gly16Arg } & \\
\hline PPARG2 Pro12Ala & \multicolumn{2}{|c|}{ Gly/Gly } & \multicolumn{2}{|c|}{ Gly/Arg or Arg/Arg } & \\
\hline Pro/Pro & $44 / 49$ & 1 (ref.) & $73 / 67$ & $1.19(0.70-2.0)$ & \\
\hline Pro/Ala or Ala/Ala & $9 / 23$ & $0.41(0.17-0.99)$ & $26 / 9$ & $1.64(0.79-3.4)$ & 0.035 \\
\hline
\end{tabular}

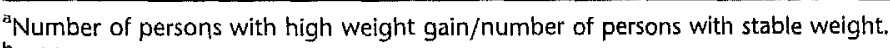

${ }^{b}$ Odds ratios.

men. Furthermore, positive and negative associations were found between the Glu27 variant of the ADRB2 gene with BMI, fat mass or fat cell volume in French, Swedish and Japanese subjects. ${ }^{21,38,39}$ Also, associations were found between polymorphisms in the UCP2 gene and weight gain, obesity or metabolic rates, ${ }^{17,30,31}$ between variants in the UCP1 gene and weight gain, weight, or BMI loss, ${ }^{32-34}$ between polymorphisms in the LEPR gene and percentage body fat or $\mathrm{BMI}_{1}{ }^{35-37}$ and between polymorphisms in the PPARG2 gene and BMI, gain in BMI or leptin levels. ${ }^{38-42}$ However, studies showing no associations for these polymorphisms have also been published. ${ }^{22,37,42-51}$ In the present study, we could not find associations between all of these polymorphisms with weight gain in men and women. These essentially negative results might be explained by several factors. First, it is important to recognize that we have used only one among several potentially useful phenotypes. Indeed, our design is a comparison between high weight gainers and non-weight gainers. It would be useful also to investigate the effect of the genetic polymorphisms on the distribution of weight gain adjusted for baseline body weight, separately in men and women. Moreover, since in the regulation of body weight food-seeking behavior, energy expenditure and complex interactions among these traits are likely to be involved, not for all obesity phenotypes are similarly associated with these polymorphisms. However, even the few studies on the association between genetic factors and weight gain showed inconsistent results. One study also reported a lack of association between the UCP2 Ins/Del and weight gain in Danish Caucasians ${ }^{47}$ but Clement et al reported an association between the UCP1 A(-3826)G polymorphism and weight gain. ${ }^{32}$ However, the latter was performed on morbidly obese patients, while we investigated the impact of genetic factors on weight gain in a general population.

Another reason for the apparent discrepancies in results may have to do with lack of statistical power. Although we have selected our study population in order to get the largest contrast, the number of subjects might still be too small to be able to detect a significant association, especially for a relatively rare polymorphism such as the Pro12Ala mutation in the PPARG2 gene. Therefore, it would be useful to investigate these associations in a larger population. Thirdly, differences in ethnic background could account for some of the differences in findings. For instance, some associations were only in Pima Indians or Japanese subjects. ${ }^{17,30,53}$ Finally, the variety in the prevalence of environmental risk factors might explain the diversity in the strength of the associations. For example, if there is only an effect of the genetic predisposition in the presence of another environmental factor for weight gain, it is likely that associations will be found preferentially in these populations in which 
the environmental factor while in other population where the risk factor is rare, no associations will be found.

Thus, the ADRB2-Gly 16Arg polymorphism was associated with weight gain in our population. However for several reasons, one should be careful with drawing conclusion from this. As we used a significance level of 0.05 and conducted many analyses, we cannot rule out chance as an explanation. Furthermore, the direction of the association among men is equivocal. As receptor function experiments have shown that the Gly16Arg polymorphism in the ADRB2 gene is associated with an altered receptor function one would expect a higher prevalence of the Gly/Gly genotype among the weight gainers compared to that of the non-weight gainers. $^{21,54}$ Our study is not the first one to show sexspecific associations for the ADRB2 gene. Hellstrom et al reported a higher prevalence of the Glu27 variant of the $A D R B 2$ gene among female obese, compared to a decreased prevalence among male obese. ${ }^{28}$ Meirhaeghe et al suggested that among women an altered pathway may be more efficiently compensated by a decrease in the alpha 2 adrenergic pathway compared to men. ${ }^{26}$ Therefore, more refined association studies and experimental work on this polymorphism are needed.

From all genetic marker combinations, we found only four combinations that were associated with weight gain. However, given the number of statistical tests performed, it is likely that they are by chance. Before we draw conclusions from these analyses, these findings have to be confirmed in other studies. For this reason, we are currently increasing the sample size with the aim of confirming some of the associations and investigating the interactions between genes and between genes and lifestyle factors.

Since we only observed weak associations between genetic and behavioral factors with weight gain, the question remains why the majority of persons who gain weight do so. Our observation that not the food habits during breakfast, lunch and dinner are important (such as type of spread used and so on), but to some extent the use of alcohol and savory snacks deserves further study. In addition, leisure inactivity was shown to be predictive of weight gain in women. The association between lifestyle factors and weight gain requires further study.

In summary, none of the studied genetic markers are clearly associated with weight gain. Only variations in the ADRB2 gene and the LEPR gene may contribute to the susceptibility to weight gain, but replication studies are needed. Further research is necessary to establish the role of lifestyle factors, or interactions between genes or between genes and lifestyle factors on weight gain.

\section{Acknowledgements}

The Cardiovascular Disease Risk Factor Monitoring Study (PEILSTATION) and the Monitoring Project on Risk Factors for Chronic Diseases (MORGEN-project) was financially supported by the Ministry of Health, Welfare and Sport of The
Netherlands and the National Institute of Public Health and the Environment. The authors would like to thank the epidemiologists and field-workers of the Municipal Health Services in Doetinchem and Maastricht for their important contribution to the data collection for this study. The authors wish to thank GL Obermann-de Boer for coordinating the PEILSTATION-project. The project steering committee of MORGEN project consisted of Dr $\mathrm{HB}$ Bueno de Mesquita, Dr HA Smit, Dr WMM Verschuren and Dr JC Seidell (project leader). Project leader of the follow-up measurements in Maastricht was Dr AJ Schuit. Logistic management was provided by $A$ Jansen and J Steenbrink and data management by A Blokstra, P Steinberger and A van Kessel. Furthermore, we gratefully acknowledge $\mathrm{K}$ Wichers and $\mathrm{H}$ Hodemaekers, who did a part of the PCR analyses. CTM van Rossum is supported by the Dutch Scientific Organization (NWO). C Bouchard is supported in part by the George A Bray Chair in Nutrition.

\section{References}

1 WHO. Obesity: preventing and managing the global epidemic. WHO: Geneva; 1997.

2 Hill JO, Peters JC. Environmental contributions to the obesity epidemic. Science 1998; 280: 1371-1374.

3 Lindroos AK, Lissner L, Carlsson B, Carlsson LM, Torgerson J, Karlsson C, Stenlöf K, Sjöström L. Familial predisposition for obesity may modify the predictive value of serum leptin concentrations for long-term weight change in obese women. Am I Clin Nutr 1998; 67: 1119-1123.

4 Stunkard AJ, Harris JR, Pedersen NL, McClearn GE. The bodymass index of twins who have been reared apart. New Engl / Med 1990; 322: 1483-1487.

5 Bouchard C, Tremblay A, Després J-P, Nadeau A, Lupien PJ, Thériault $G$, Dussault J, Moorjani $S$, Pinault $S$, Fournier $G$. The response to long-term overfeeding in identical twins. New Engl J Med 1990; 322: 1477-1482.

6 Comuzzie AG, Allison DB. The search for human obesity genes. Science 1998; 280: 1374-1377.

7 Barsh GS, Faroogi IS, O'Rahilly S. Genetics of body-weight regulation. Nature 2000; 404: 644-651.

8 Chagnon YC, Pérusse L, Weisnagel SJ, Rankinen T, Bouchard C. The human obesity gene map: the 1999 update. Obes Res 2000; 8: $89-117$.

9 Schrauwen $\mathrm{P}$, Walden $\mathrm{K}$, Ravussin E. Human uncoupling proteins and obesity. Obes Res 1999; 7: 97-105.

10 Frühbeck $G$, Salvador J. Relation between leptin and the regulation of glucose metabolism. Diabetologia 2000; 43: 1 .

11 Lönnqvist F, Nordfors L, Schalling $M$. Leptin and its potential role in human obesity. I Intern Med 1999; 245: 643-652.

12 Auwerx J. PPARgamma, the ultimate thrifty gene. Diabetologia 1999; 42: 1033-1049.

13 Arner P, Hoffstedt J. Adrenoceptor genes in human obesity. Intern Med 1999; 245: 667-672.

14 Verschuren WMM, van Leer EM, Blokstra A, Seidell JC, Smit HA, Bueno de Mesquita HB, Obermann-de Boer GL, Kromhout D. Cardiovascular disease risk factors in The Netherlands. Neth 7 Cardiol 1993; 6: 205-210.

15 Korkeila M, Kaprio J, Rissanen A, Koskenvuo M. Consistency and change of body mass index and weight. A study on 5967 adult Finnish twin pairs. Int J Obes Relat Metab Disord 1995; 19: 310317.

16 Bloemberg BPM.On the effect of measurement error in nutritional epidemiology using dietary history and food frequency methodology. Leiden: Rijksuniversiteit Leiden; 1993. 
17 Walder $\mathrm{K}$, Norman RA, Hanson RL, Schrauwen $\mathrm{P}$, Neverova $\mathrm{M}$ Jenkinson $\mathrm{CP}$, Easlick J, Warden $\mathrm{CH}$, Pecqueur C, Raimbault S, Ricquier D, Silver MHK, Shuldiner AR, Solanes G, Lowell BB, Chung WK, Leibel RL, Pratley R, Ravussin E. Association between uncoupling protein polymorphisms (UCP2-UCP3) and energy metabolism/obesity in Pima Indians. Hum Mol Genet 1998; 7: $1431-1435$.

18 Cassard-Doulcier AM, Bouillaud F, Chagnon M, Gelly C, Dionne FT, Oppert JM, Bouchard $\mathrm{C}$, Chagnon $\mathrm{Y}$, Ricquier D. The $\mathrm{Bcl} I$ polymorphism of the human uncoupling protein (ucp) gene is due to a point mutation in the 5 'flanking region. Int J Obes Relat Metab Disord 1996; 20: 278279.

19 Yen C-J, Beamer BA, Negri C, Silver K, Brown KA, Yarnall DP, Burns DK, Roth J, Shuldiner AR. Molecular scanning of the human peroxisome proliferator activated receptor gamma (hPPARgamma) gene in diabetic Caucasians: identification of a Pro12Ala PPAR gamma 2 missense mutation. Biochem Biophys Res Commun 1997; 241: 270-274.

20 Chung WK, Kehoe LP, Chua M, Chu F, Aronne L, Huma Z, Sothern M, Udail JN, Kahle B, Leibel RL. Exonic and intronic sequence variation in the human leptin receptor gene (LEPR). Diabetes 1997; 46: 1509-1511.

21 Large $V$, Hellström L, Reynisdottir $S$, Lönnqvist $F$, Eriksson $P_{t}$ Lannfelt L, Arner P. Human beta-2 adrenoceptor gene polymorphisms are highly frequent in obesity and associate with altered adipocyte beta-2 adrenoceptor function. I Clin Invest 1997: 100: 3005-3013

22 Echwald SM, Sørensen TD, Sørensen TIA, Hansen A'T-H, Andersen $T$, Chung $W K$, Leibel $R L$, Pedersen $O$. Amino acid variants in the human leptin receptor: lack of association to juvenile onset obesity. Biochem Biophys Res Commun 1997; 233: $248-252$.

23 Schaid DJ, Jacobsen SJ. Baised tests of association: comparisons of allele frequencies when departing from Hardy-Weinberg proportions. Am J Epidemiol 1999; 149: 706-711.

24 Ravussin E, Gautier J-F. Metabolic predictors of weight gain. Int J Obes Relat Metab Disord 1999; 23(Suppl 1): 37-41.

25 Rowland ML. Self-reported weight and height. Am I Clin Nutr 1990; 52: $1125-1133$.

26 Meirhaeghe A, Helbecque N, Cottel D, Amouyel P. Impact of polymorphisms of the human beta2-adrenoceptor gene on obesity in a French population. Int J Obes Relat Metab Disord 2000; 24: $382-387$.

27 Ishiyama-Shigemoto S, Yamada X, Ichikawa K, Nonaka K. Association of polymorphism in the beta2-arenergic receptor gene with obesity, hypertriglyceridaemia, and diabetes mellitus. Diabetologia 1999; 42: $98-101$.

28 Hellström L, Large V, Reynisdottir S, Wahrenberg H, Arner P. The different effects of a Gln27Glu beta(2)-adrenoceptor gene polymorphism on obesity in males and in females. / Intern Med 1999; 245: $253-259$.

29 Mori $\mathrm{Y}$, Kim-Motoyama $\mathrm{H}_{\text {r }}$ Ito $\mathrm{Y}$, Katakura $\mathrm{T}$, Yasuda $\mathrm{K}$ Ishiyama-Shigemoto $S$, Yamada $K$, Akanuma $Y$, Ohashi $Y$, Kimura S, Yazaki Y, Kadowaki T. The GIn27Glu beta2-adrenergic receptor variant is associated with obesity due to subcutaneous fat accumulation in Japanese men. Biochem Biophys Res Commun 1999; 258: 138-140.

30 Cassell PG, Neverova $\mathrm{M}$, Janmohamed $\mathrm{S}$, Uwakwe $\mathrm{N}$ Qureshi A, McCarthy MI, Saker PJ, Albon L, Kopelman P, Noonan $\mathrm{K}$, Easlick J, Ramachandran A, Snehalatha $\mathrm{C}$ Pecqueur C, Ricquier D, Warden C, Hitman GA. An uncoupling protein 2 gene variant is associated with a raised body mass index but not type Il diabetes. Diabetologia 1999; 42 : $688-692$.

31 Astrup A, Toubro S, Dalgaard LT, Urhammer SA, Sørensen TIA, Pederson $O$. Impact of the $\mathrm{v} / \mathrm{v} 55$ polymorphism of the uncoupling protein 2 gene on 24-h energy expenditure and substrate oxidation. Int I Obes Relat Metab Disord 1999; 23: $1030-1034$
32 Clément K, Ruiz J, Cassard-Doulcier AM, Bouillaud F, Ricquier D, Basdevant A, Guy.Grand B, Froguel P. Additive effect of $A \rightarrow G$ $(-3826)$ variant of the uncoupling protein gene and the Trp64Arg mutation of the beta 3 -adrenergic receptor gene on weight gain in morbid obesity. Int JObes Relat Metab Disord 1996; 20: 1062-1066.

33 Fumeron F, Durack-Bown I Betoulle D, Cassard-Doulcier AM, Tuzet S, Bouillaud F, Melchior JC, Ricquier D, Apfelbaum M. Polymorphisms of uncoupling protein (UCP) and beta 3 adrenoreceptor genes in obese people submitted to a low calorie diet. Int I Obes Relat Metab Disord 1996; 20: 1051-1054

34 Oppert J-M, Vohl MC, Chagnon M, Dionne FT, Cassard-Doulcier AM, Ricquier D, Pérusse L, Bouchard C. DNA polymorphism in the uncoupling protein (UCP) gene and human body fat. Int) Obes Relat Metab Disord 1994; 18: 526-531.

35 Thompson DB, Ravussin E, Bennett PH, Bogardus C. Structure and sequence variation at the human leptin receptor gene in lean and obese Pima Indians. Hum Mol Genet 1997; 6: 675-679.

36 Rosmond R, Chagnon $\mathrm{YC}_{\text {, Holm }} \mathrm{G}$, Chagnon $\mathrm{M}$, Perusse $\mathrm{L}$, Lindell K, Carlsson B, Bouchard C, Bjorntorp P. Hypertension in obesity and the leptin receptor gene locus. J Clin Endocrinol Metab 2000; 85: 3126-3131

37 Gotoda T, Manning BS, Goldstone AP, Imrie H, Evans AL, Strosberg AD, McKeigue PM, Scott J, Aitman TJ. Leptin receptor gene variation and obesity: lack of association in a white British male population. Him Mol Genet 1997; 6: 869-876.

38 Deeb SS, Fajas L, Nemoto M, Pihlajamaki J, Mykkänen L, Kuusisto J, Laakso M, Fujimoto W, Auwerx J. A Pro12Ala substitution in PPARgamma2 associated with decreased receptor activity, lower body mass index and improved insulin sensitivity. Nature Genet 1998; 20: 284-287.

39 Beamer BA, Yen C-J, Andersen RE, Muller D, Elahi D, Cheskin LJ, Andres R, Roth ], Shuldiner AR. Association of the Pro12Ala variant in the peroxisome proliferator-activated receptor gamma 2 gene with obesity in two Caucasian populations. Diabetes 1998; 47: 1806-1808.

40 Ek J, Urhammer SA, Sørensen TIA, Andersen T, Auwerx J, Pedersen $\mathrm{O}$. Homozygosity of the Pro12Ala variant of the peroxisome proliferation-activated receptor-gamma2 (PPAR-gamma2); divergent modulating effects on body mass index in obese and lean Caucasian men. Dinbetologia 1999; 42: 892-895.

41 Cole SA, Mitchell BD, Hsueh W-C, Pineda P, Beamer BA, Shuldiner AR, Comuzzie AG, Blangero J, Hixson JE. The Pro12Ala variant of peroxisome proliferator-activated receptor-gamma2 (PPAR-gamma2) is associated with measures of obesity in Mexican Americans. Int I Obes Relat Metab Disord 2000; 24 $522-524$.

42 Meirhaeghe A, Fajas L, Helbecque $\mathrm{N}$, Cottel D, Lebel P, Dallongeville J, Deeb S, Auwerx J, Amouyel P. A genetic polymorphism of the peroxisome proliferator-activated receptor gamma gene influences plasma leptin levels in obese humans. Hum Mol Genet 1998; 7: $435-440$.

43 Oberkofler $H$, Esterbauer $H$, Hell E, Krempler $F$, Patsch W. The GIn27Glu polymorphism in the beta2-adrenergic receptor gene is not associated with morbid obesity in Austrian women. Int J Obes Relat Metab Disord 2000; 24: 388-390.

44 Kortner B, Wolf A, Wendt D, Beisiegel U, Evans D. Lack of association between a human beta-2 adrenoceptor gene polymorphism (gln27glu) and morbid obesity. Int J Obes Relat Metab Disord 1999; 23: 1099 - 1100 .

45 Urhammer SA, Dalgaard LT, Sørensen TIA, Moller AM, Andersen T, Hansen AT-H, Hansen T, Clausen JO, Vestergaard $\mathrm{H}$, Pedersen $\mathrm{O}$. Mutational analysis of the coding region of the uncoupling protein 2 gene in obese NIDDM patients: impact of a common amino acid polymorphism on juvenile and maturity onset forms of obesity and insulin resistance. Diabetologia 1997; 40: 1227-1230.

46 Kubota $\mathrm{T}$, Mori $\mathrm{H}$, Tamori $\mathrm{Y}$, Okazawa $\mathrm{H}$, Fukuda $\mathrm{T}$, Miki $\mathrm{M}$, Ito $\mathrm{C}$, Fleury C, Bouillaud F, Kasuga M. Molectlar screening of uncoupling protein 2 gene in patients with noninsulin-dependent diabetes mellitus or obesity. I Clin Endocrinol Metab 1998; 83: $2800-2804$. 
47 Dalgaard LT, Sørensen TIA, Andersen T, Hansen T, Pedersen O. An untransiated insertion variant in the uncoupling protein 2 gene is not related to body mass index and changes in body weight during a 26-year follow-up in Danish Caucasian men. Diabetologia 1999; 42: $1413-1416$.

48 Urhammer SA, Fridberg M, Sørensen TIA, Echwald SM, Andersen T, Tybjaerg-Hansen A, Clausen JO, Pedersen O. Studies of genetic variability of the uncoupling protein 1 gene in Caucasian subjects with juvenile-onset obesity. $J$ Clin Endocrinol Metab 1997; 82: $4069-4074$.

49 Gagnon J, Lago F, Chagnon YC, Pérusse L, Näslund I, Lissner L, Sjöström L, Bouchard C. DNA polymorphism in the uncoupling protein 1 (UCP1) gene has no effect on obesity related phenotypes in the Swedish Obese Subjects cohorts. Int / Obes Relat Metab Disord 1998; 22: 500-505.

50 Matsuoka N, Ogawa Y, Hosoda K, Matsuda J, Masuzaki H, Miyawaki T, Azuma N, Natsui K, Nishimura $H$, Yoshimasa Y, Nishi S, Thompson DB, Nakao K. Human leptin receptor gene in obese Japanese subjects: evidence against either obesity-causing mutations or association of sequence variants with obesity. Diabetologia 1997; 40: 1204-1210.
51 de Silva A, Walder $K$, Aitman $T$, Gotoda T, Goldstone A, Hodge A, de Courten $M$, Zimmet P, Collier $G$. Combination of polymorphisms in $O B-R$ and the $O B$ gene associated with insulin resistance in Nauruan males. Int J Obes Relat Metab Disord 1999; 23: 816822.

52 Clement $\mathrm{K}$, Hercberg S, Passinge B, Galan P, Varroud-Vial M, Shuldiner AR, Beamer BA, Charpentier G, Guy-Grand B, Froguel P, Vaisse $C$. The Pro115Gln and Prol2Ala PPAR gamma gene mutations in obesity and type 2 diabetes. Int J Obes Relat Metab Disord 2000; 24: $391-393$.

53 Valve R, Sivenius K, Miettinen R, Pihlajamäki J, Rissanen A, Deeb SS, Auwerx J, Uusitupa $M$, Laakso $M$. Two polymorphisms in the peroxisome proliferator-activated receptor-gamma gene are associated with severe overweight among obese women. J Clin Endocrinol Metab 1999; 84: 3708-3712.

54 Green SA, Turki J, Hall IP, Liggett SB. Implications of genetic variability of human beta 2-adrenergic receptor structure. Pllm Pharmac 1995; 8: 1-10. 